\title{
Effect of variety and apron star on incidence and severity of cercospora leaf spot disease of cowpea (Vigna unguiculata) in Sokoto, North-Western Nigeria
}

\begin{abstract}
Field study was conducted during the 2015 raining season, at the Usmanu Danfodiyo University, Dry land farm, to evaluate the effect of Cercospora leaf spot disease and seed dressing chemical (Apron star) on different varieties of cowpea viz. Sampea-7, Sampea-8, Sampea-9, Sampea-11, Sampea-15 and Ex-Yumfa. Randomize Complete Block Design was used for the study. Results revealed that all the varieties were infected by Cercospora leaf spot disease at varying level. Ex-yumfa had highest disease incidence and severity both at 9 WAS and at harvest $(40.385 \%$ and $55.128 \%$ incidence at 9 WAS and at harvest respectively) and (35.537\% and $65.186 \%$ severity at 9 was and at harvest). Lowest disease incidence was observed both at 9 WAS and at harvest on Sampea-15 (19.911\% at 9 WAS and $28.884 \%$ incidence at harvest) and (11.911\% and $21.852 \%$ severity) and no significant difference was recorded between dressed and undressed. Ex-Yumfa had lowest 100 grain (g) weight and yield per ha-1 while Sampea-7,8,9 and 11 are statistically similar also, there was no significant difference between dressed and undressed seeds in 100 grains weight seed and yield.
\end{abstract}

Keywords: variety, seed dressing chemical, disease incidence, disease severity, cowpea yield
Volume 5 Issue I - 2018

\author{
Muhammad AS,' Sajo AY,' Bello I,' Haliru BS,' \\ Bagudo HA,' Mohammed IU,' Sanda A \\ 'Department of Crop Science, Usmanu Danfodiyo University, \\ Nigeria \\ ${ }^{2}$ Department of Crop Science, Kebbi State University of Science \\ and Technology, Nigeria \\ ${ }^{3}$ Department of Biological Sciences, Usmanu Danfodiyo \\ University, Nigeria
}

\begin{abstract}
Correspondence: Muhammad AS, Department of Crop Science, Usmanu Danfodiyo University, Sokoto, Nigeria, Emailabkrgwn@yahoo.co.uk
\end{abstract}

Received: November 22, 2017 | Published: January 29, 2018

\section{Introduction}

Cowpea (Vigna unguiculata L.) Walp is known to be affected by several fungal, bacterial and viral diseases. One of such fungal diseases reported to cause serious yield loss in the cowpea is the Cercospora leaf spot disease caused by two fungi namely, Cercospora canescens Ellis and Martin and Cercospora cruenta. ${ }^{1}$ Yield loss attributed to Cercosora leaf spot in susceptible cowpea variety varies between $36 \%$ and $42 \%{ }^{2}$ Out of 75 cowpea varieties evaluated in 1999 and 2000 , about $42 \%$ of the germplasm was found to be susceptible to Cercospora diseases, ${ }^{3}$ with Ife brown having $80 \%$ Cercospora incidence on the field. According to Booker and Pathmanathan, a Cercospora leaf spot disease is a serious limitation to cowpea production, resulting in yield loss of as much as 42 percent. Due to the high cost of chemicals used in the control of Cercospora leaf spot disease of cowpea, equipment, and misuse of these chemicals, which cause a harmful effect in the environment, has been the major factors that necessitate the search for other methods of disease management. It therefore, the use of resistance varieties, thus, can help to reduce the incidence and severity of Cercospora leaf spot disease of cowpea.

\section{Therefore the objectives of this study are}

i. To evaluate cowpea varieties for resistance to Cercospora leaf spot disease of cowpea.

ii. To determine the effect of seed dressing chemical (Apron star) on Cercospora leaf spot disease of cowpea.

\section{Materials and methods}

The experiment was carried out at the Dry land Teaching and Research Farm of Crop Science Department, Usmanu Danfodiyo University, Sokoto, during the 2015 cropping season. The farm is located along Usmanu Danfodiyo University Model Secondary School. Sokoto is located in Sudan savanna on latitude $13^{\circ} 01^{1} \mathrm{~N}$ and longitude $5^{0} 15^{1} \mathrm{E}$; The soil is sandy and lies at an altitude of $350 \mathrm{~m}$ above sea level, with minimum and maximum temperature of $15^{\circ} \mathrm{C}$ and $40^{\circ} \mathrm{C}$ respectively ${ }^{4}$ and $645 \mathrm{~mm}$ of rainfall. ${ }^{5}$

\section{Treatments and experimental design}

The treatment consists of five improved cowpea varieties. Sampea-7, Sampea-8, Sampea-9, Sampea-11 and Sampea-15. The cowpea varieties were sourced from Institute of Agricultural research Samara, Zaria (IAR), Department of Crop Science, Seed production unit, and one local variety, Ex-gidan Yunfa which were obtained from Gidan yumfa Village.

The Experiment was laid out in a Randomized Complete Block Design (RCBD) made up 36 plots, with three (3) replications, each block having 12 plots; each plot measured $4 \times 3 \mathrm{~m}\left(12 \mathrm{~m}^{2}\right)$. Each plot consists of four (4) rows spaced at $75 \mathrm{~cm}$ and $30 \mathrm{~cm}$ intra row. The blocks and plots were separated by an alley way of $1 \mathrm{~m}$ and $0.5 \mathrm{~m}$ respectively.

\section{Cultural practices}

Land preparation: The land was cleared of shrubs and stubbles, and ploughed with a tractor. The soil was prepared to provide sufficient tilth for good root growth. 
Seed dressing: Seed dressing was carried out according to the treatment with undress as control.

Sowing: Sowing was carried out on 06/07/2015 at a spacing of $75 \mathrm{~cm}$ between rows (inter-row spacing) and $30 \mathrm{~cm}$ intra-row spacing. The sowing was carried out with the use of thread and pegs to make straight lines and to plant the seed at regular intervals.

Fertilizer application: Fertilizer was applied at the rate of $15 \mathrm{~kg} /$ ha $\mathrm{N}$ as a starter dose for good crop and phosphorus in the form of single super phosphate, at the $30 \mathrm{~kg}$ p/ha recommended for cowpea production to help the crop to nodulate well and fix its own nitrogen from the air.

Weeding: Weeding was carried out at two, five, and nine weeks after planting.

Insecticide application: Cowpea plant was protected from insect attack by application of Cypermethrin+Dimethoate insecticide at the rate of $50 \mathrm{~g}$ a.i./ha. It was done at flowering and podding stages.

Data collection: Growth parameters, Stand establishment count, Plant establishment count was taken for each plot using the following formula:

$$
\text { Establishment count }=\frac{\text { Established plants }}{\text { Number of seed sown }} \times 100
$$

Plant height (m): This was done at nine weeks after sowing (WAS) and at harvest, five plants were randomly selected and were measured from the soil level to the terminal bud using meter rule.

Days to first flowering: Number of days to first flower was noticed by regular visiting to experimental area after planting.

Days to $\mathbf{5 0 \%}$ flowering: Number of Days at which $50 \%$ of the plants have produced flower was counted per plot. This was done by regular visit to the field and visual observation.

Number of branches per plant: Number of branches was determined by visual counting of the number of leaves per plant.

\section{Disease parameters}

Disease incidence: Data on incidence of the disease was taken at 9 weeks after sowing, number of stand showing symptoms of the disease in each plot was counted and expressed as percentage of the number of stand in each plot using the following formula.

Disease incidence $=\frac{\text { Number of infected stands }}{\text { Number of total stand in the plot }} \times 100$

Disease severity: Severity of the disease was determined using a scale of 1-9. Five plants were selected at random which were observed and scored based on the extent of disease establishment on each, a scale number was assigned.

\section{Disease severity scale}

$$
\begin{aligned}
& 0=\text { Not infected } \\
& 1=\text { slightly infected } \\
& 3=\text { slightly moderately infected } \\
& 5=\text { moderately infected } \\
& 7=\text { less severely infected }
\end{aligned}
$$

$9=$ severely infected

$$
\text { Disease Severity }=\frac{\sum n}{N X 9} x 100
$$

Where,

DS $=$ Cercospora leaf spot severity (\%)

$\sum_{\mathrm{n}}=$ Summation of Individual ratings

$\mathrm{N}=$ Total number of plant assessed

$9=$ Highest score on the severity scale

Yield parameters: Number of pods per plant. At the end of trial, five cowpea plants were randomly selected and their number of pods was taken, average obtained.

Harvesting: Harvesting was carried out by harvesting all the pods and cutting the main plant. Weight of 100 Seed $(\mathrm{g})$. At the end of the study 100 seeds of cowpea from each plot were counted, weighed for each treatment.

Seed yield: At the end of the study seed yield per plot was obtained by weighing the seeds from each treatment and projected to per hectare.

Data analysis: Data collected were subjected to analysis of variance (ANOVA) based on Randomized Complete Block Design, while significant means were separated using the Duncan's multiple range test (DMRT), at 5\% level of significance.

\section{Results and discussion}

\section{Establishments count}

The effect of seed dressing chemical and variety on stand establishment count during 2015 cropping season is presented on Table 1 . The result reveal that, the treatments were at per statistically different $(\mathrm{P}<0.05)$ Seeds dressed with Apron star gave highest number of established plants than undressed. This could be as a result of the effect of Apron star, which helped in germination by controlling seed borne and seedling disease, as stated by Ebofin. ${ }^{6}$ The table also reveal the effect of variety on establishment count, where Ex-Yumfa had highest number of established plants and lowest was recorded on Sampea-9. Sampea-7, Sampea-8, Sampea-11 and Sampe-15 are statistically similar. The observed varietal differences in germination percentage may be related to differences in seed size. Borji et al. ${ }^{7}$ observed that inhibition of establishment may be related to seed coat thickness, number of seed coat pores and seed size. Also there is no significant different between the interaction of variety and fungicide.

\section{Plant height}

Result of effect of fungicide and variety on plant height at 9WAS and at harvest is presented in the Table 2 . Both fungicide and variety produced significant $(\mathrm{P}<0.05)$ effect on plant height. Seed dressed with Apron star differed significantly $(\mathrm{P}<0.05)$ both at 9 WAS and at harvest. The highest mean of plant height was recorded on seeds treated with the fungicide both at 9 WAS and at harvest. The differences observed both at 9WAS and at harvest may be due to protection offered by Apron star against soil, foliar diseases and pest. This is in agreement with Richards et al., ${ }^{8}$ who reported that seed dressing with Apron star gave protection against soil and foliar diseases which may hinder crop growth. 
The Table 2 also revealed the result of plant height as influenced by variety both at 9WAS and at harvest with Sampea-15 having highest plant height both at 9WAS and at harvest and lowest plant height at 9WAS was obtained from Sampea-11 and Sampea-11 at harvest. While Sampea-7 and Sampea-8 are statistically similar at 9WAS, and Sampea-7 and Sampea-8 are similar at harvest. The varietal differences observed on plant height under the same environmental condition may be an inherent trait peculiar to each of the varieties.

\section{Disease incidence at 9 weeks after sowing and at harvest}

Table 3 indicates the effect of fungicide and variety on disease incidence at 9WAS and at harvest. The result from the table revealed that, there was no significant difference $(\mathrm{P}>0.05)$ on disease incidence at 9WAS and at harvest between dressed and undressed seeds, but significant difference $(\mathrm{P}<0.05)$ exists between the verities, where ExYumfa had highest disease incidence both at 9WAS and at harvest, and lowest was observed on Sampea-15 both at 9WAS and at harvest, followed by Sampea-7 at 9WAS, and Sampea-8, Sampea-9, and Sampea-11 are statistically similar at 9WAS and Sampea-7, Sampea-8 and Sampea-9 are similar at harvest. The differences observed in disease incidence between the varieties may be due to the inherent genetic make-up of the varieties, which is supported by Allerd et al. ${ }^{9}$ They reported that varieties react differently to diseases due to their different inherent genetic make-up. There was no significant effect between variety and fungicide.

\section{Disease severity at 9 weeks after sowing and at harvest}

Table 3 also indicates the effect of fungicide and variety on disease severity at 9 WAS and at harvest. The Table showed that seed dressing had no effect on disease severity both at 9 WAS and at harvest, but difference existed between the varieties. Highest severity was observed on Ex-Yumfa both at 9 WAS and at harvest, and lowest severity was observed on Sampea-15 at 9 WAS and at harvest respectively. Similarly Sampea- 8 and Sampea-9 are statistically similar at 9 WAS, but differ significantly at harvest. The 6 varieties react differently on their level of disease incidence and severity to Cercospora cruenta and canescens, which indicated that varieties have different level of resistance to the disease. This may be due to the inherent genetic make-up of the varieties to resist the disease at different levels. ${ }^{9,10}$

\section{Weight of 100 grains}

The result of effect of fungicide and variety on 100 grains weight is presented in Table 4. The result showed that, there was no significant $(\mathrm{P}>0.05)$ difference between dressed and undressed seeds but significant $(\mathrm{P}<0.05)$ difference exist between the varieties. Highest mean of 100 grains weight was obtained on Sampea-9 and lowest was obtained from Ex-Yumfa, while Sampea-9, Sampea-8, Sampea-11 and Sampea-15 are statistically the same. This may be as a result of effect of Cercospora leaf spot on the performance of the variety ${ }^{11}$ coupled with the ability of varieties to accumulate assimilates under the disease condition.

\section{Seed Yield}

The result of effect of variety and fungicide on Seed yield is presented in the Table 4. Table showed that there was no significant $(\mathrm{P}>0.05)$ difference between dressed and undressed seeds on seed yield per ha ${ }^{-1}$. But significant $(\mathrm{P}<0.05)$ difference exist between the varieties, where Ex-Yumfa produced significantly $(\mathrm{P}<0.05)$ lower than
Sampea-7, Sampea-8, Sampea-9, Sampea-11 and Sampea-15 in terms of yield per ha ${ }^{-1}$. Which might be due to high leaves defoliation on Exgidan yumfa. This was in agreement with the finding of Booker and Pathmanthan who reported that, Cercospora cruenta and canescens have a serious effect on yield under severe infestation up to $42 \%$ loss in yield. Furthermore, Plantwise ${ }^{11}$ also reported that seed yield of cowpea was correlated with Cercospora leaf spot disease severity from artificially and naturally occurring epidemics at Ibadan.

Table I Establishment count of cowpea as influenced by variety and seed dressing during 2015 cropping season in Sokoto

\begin{tabular}{ll}
\hline Treatments & Establishment count (\%) \\
\hline Fungicide & \\
Dressed & 94.132 \\
Undressed & 84.373 \\
SE \pm & 1.716 \\
Significance & $*$ \\
Variety & \\
Sampea-7 & $88.717^{\mathrm{ab}}$ \\
Sampea-8 & $87.306^{\mathrm{ab}}$ \\
Sampea-9 & $79.724^{\mathrm{b}}$ \\
Sampea-11 & $83.872^{\mathrm{ab}}$ \\
Sampea-15 & $89.231^{\mathrm{ab}}$ \\
Ex-Yumfa & $91.667^{\mathrm{a}}$ \\
SE \pm & 2.972 \\
Significance & $*$ \\
Interaction & \\
VXF & $\mathrm{NS}$ \\
\hline
\end{tabular}

Means bearing the same superscript along the same column are statistically the same at $5 \%$ level of significance.

NS, Not significant;

*=Significant

Table 2 Plant height of cowpea as influenced by variety and fungicide at 9 WAS and at harvest

\begin{tabular}{lll}
\hline \multirow{2}{*}{ Treatments } & Plant height & Plant height \\
\cline { 2 - 3 } Fungicide & At 9 WAS $(\mathbf{c m})$ & At 14WAS $(\mathbf{c m})$ \\
Dressed & 165.3 & 259.5 \\
Undressed & 135.6 & 209.9 \\
Significance & $*$ & $*$ \\
SE \pm & 0.12 & 1.7 \\
Variety & & \\
Sampea-7 & $165.6^{\mathrm{b}}$ & $258.5^{\mathrm{ab}}$ \\
Sampea-8 & $160.0^{\mathrm{c}}$ & $247.6^{\mathrm{abc}}$ \\
Sampea-9 & $130.0^{\mathrm{d}}$ & $206.6^{\mathrm{cd}}$ \\
Sampea-11 & $127.0^{\mathrm{d}}$ & $200.0^{\mathrm{d}}$ \\
Sampea-15 & $173.6^{\mathrm{a}}$ & $273.4^{\mathrm{a}}$ \\
\hline
\end{tabular}


Table Continued

\begin{tabular}{lll}
\hline \multirow{2}{*}{ Treatments } & Plant height & Plant height \\
\cline { 2 - 3 } & At 9 WAS $(\mathbf{c m})$ & At 14WAS $(\mathbf{c m})$ \\
\hline Ex-Yumfa & $146.1^{\mathrm{cd}}$ & $221.7^{\mathrm{bcd}}$ \\
Significance & $*$ & $*$ \\
SE \pm & 0.104 & 0.147 \\
Interaction & & \\
VXF & $\mathrm{NS}$ & $\mathrm{NS}$ \\
\hline
\end{tabular}

Means bearing the same superscript along the same column are statistically the same at $5 \%$ level of significance according to DNMRT.

* =significant

NS, not significant;WAS, Weeks after sowing

Table 3 Influence of variety and fungicide on Cercospora leaf spot of cowpea at 9 WAS and at harvest

\begin{tabular}{llll}
\hline \multirow{2}{*}{ Treatments } & \multicolumn{2}{l}{ Disease incidence } & \multicolumn{2}{l}{ Disease severity } \\
\cline { 2 - 4 } & At 9 WAS At & At 9 WAS Aarvest & At Harvest
\end{tabular}

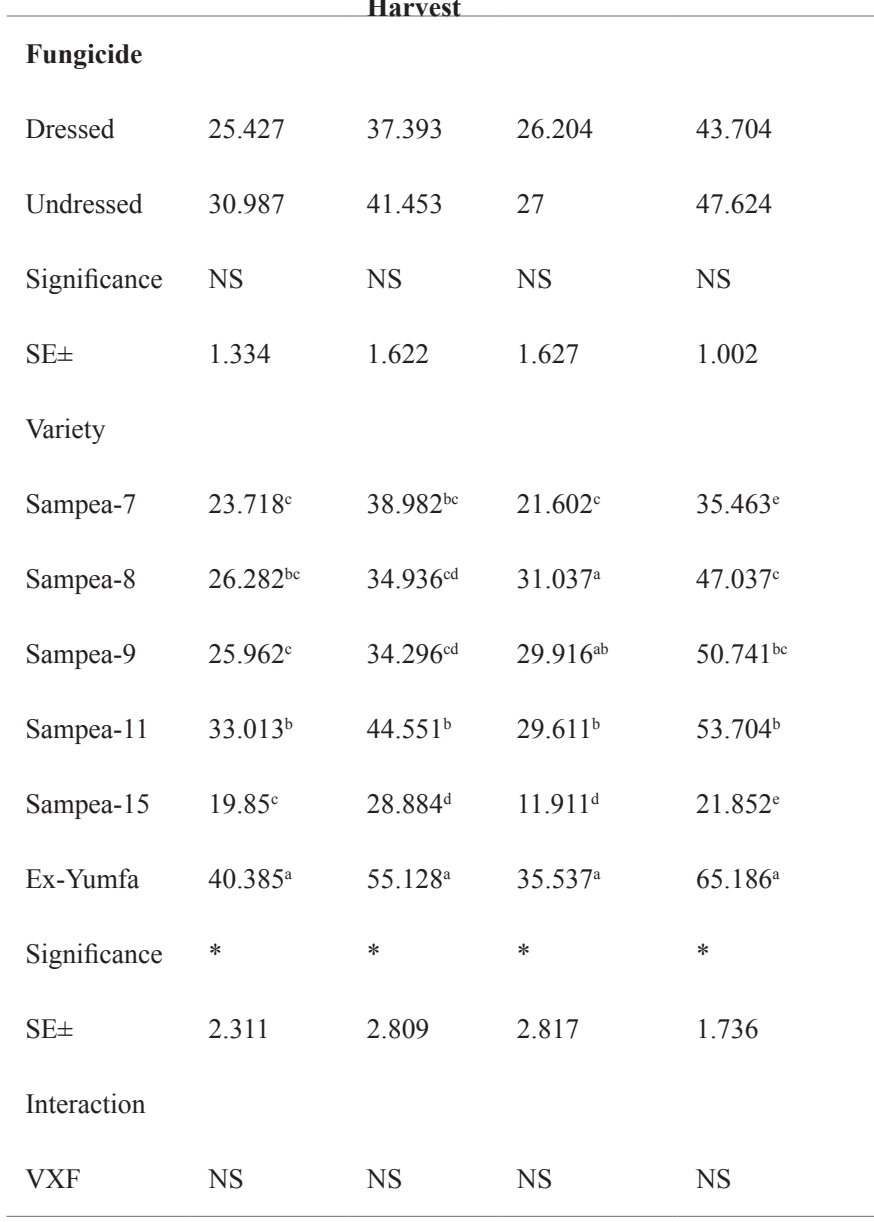

Means bearing the same superscript along the same column are statistically the same at $5 \%$ level of significance according to DNMRT.

NS= Not significant

*= Significant

WAS, Weeks after sowing.
Table 4 Effect of fungicide and variety on 100 grains weight

\begin{tabular}{lll}
\hline Treatments & $\mathbf{1 0 0}$ grain weight $\mathbf{( g )}$ & Seed yield $\mathbf{( k g / \mathbf { h a } ^ { - 1 } )}$ \\
\hline Fungicide & & \\
Dressed & 12.419 & 2456.869 \\
Undressed & 11.739 & 2838.756 \\
Significance & $\mathrm{NS}$ & $\mathrm{NS}$ \\
SE \pm & 0.322 & 642.83 \\
Variety & & \\
Sampea-7 & $12.332^{\mathrm{a}}$ & $1135.783^{\mathrm{b}}$ \\
Sampea-8 & $12.563^{\mathrm{a}}$ & $1381.267^{\mathrm{a}}$ \\
Sampea-9 & $12.713^{\mathrm{a}}$ & $1382.583^{\mathrm{a}}$ \\
Sampea-11 & $13.208^{\mathrm{a}}$ & $530.025^{\mathrm{c}}$ \\
Sampea-15 & $12.847^{\mathrm{a}}$ & $1113.100^{\mathrm{b}}$ \\
EX-Yumfa & $8.813^{\mathrm{b}}$ & $574.117^{\mathrm{c}}$ \\
Significance & $*$ & $*$ \\
SE \pm & 0.278 & 113.414 \\
Interaction & & $\mathrm{NS}$ \\
VXF & $\mathrm{NS}$ & \\
\hline
\end{tabular}

Means bearing the same superscript along the same column are statistically the same at $5 \%$ level of significance (DMRT).

NS, not significant

$*$ significant

\section{Summary}

Field study was conducted to evaluate Six Cowpea varieties for their resistance to Cercospora leaf spot disease of cowpea at the Dry land Teaching and Research farm of Crop Science Department Usmanu Danfodiyo University, Sokoto during 2015 cropping season, and also to evaluate the effect Apron star on incidence and severity of the Cercospora cruenta and canescens. Randomized Complete Block Design (RCBD) was used for the study. A scale 1-9 was used, five Plants were randomly selected from each treatment which were observed and scored based on the extent of disease establishment. From the result obtained in the study Ex-Yumfa had highest disease incidence and severity both at 9 WAS and at 14 WAS respectively. Lowest disease incidence and severity was observed on Sampea-15 at 9 WAS and at 14 WAS. The results also revealed that, fungicide had no significance effect on number of branches per plant, 100 grains weight and seed yield. Significance differences were however, observed between the varieties both interns of number of branches per plant, 100 grains weight, and seed yield, with Sampea-9 having the highest and lowest was observed on Ex-Yumfa.

\section{Conclusion}

From the result obtained in this study, it could be concluded that, all varieties were susceptible to Cercospora cruenta and $C$. canescens with Ex-Yumfa, Sampea-11 and Sampea-9 recorded with high level of susceptibility. The least susceptible variety is Sampea-15, therefore may be regarded as tolerant to Cercospora cruenta and C. canescens. Furthermore seed dressing with Apron star has no any effect on incidence and severity of the disease. 


\section{Acknowledgements}

None.

\section{Conflict of interest}

The author declares no conflict of interest

\section{References}

1. Akande RR. Genotype by environment interaction for cowpea seed yield and disease reaction in forest and dried savannah agro ecologies south west Nigeria. American Erosion Journal of Agro Culture and Science. 2005;2(2):163-168.

2. Fery RL, Dukes PD, Cuthbert FP. Yield loss of Southern peas (Vigna unguiculata) caused by cercospora leaf spot. Plant Disease Reporter. 1977;61(9):741-743.

3. Ajibade SR, Amusa NA. Effect of fungal diseases on some cowpea line in the humid environment of South West Nigeria. Journal of Sustainable Agriculture and the Environment. 2001;3(2):246-253.

4. Singh A, Baoule AL, Ahmed HG, et al. Influence of phosphorus on the performance of cowpea (Vigna unguiculata (L) Walp.) varieties in the sudan savannah of Nigeria. Trend in Advance Science and Engineering. 2011;1(3):37-42.
5. SERC. Sokoto Energy Research Centre. Nigeria: Usmanu Danfodiyo University Sokoto; 2015

6. Ebofin AO. Some Physiological Studies on seed germination and seedling growth of three savanna tree. Biological Sciences, Abeokuta, Nigeria: University of Agriculture; 2008. 1 p.

7. Borji M, Ghorbanli M, Sarlak M. Some seed trait and their relationship to seed germination, emergence rate, electrical conductivity to commo bean (Phaseolus vulgaris L). Asian Journal of Plant Sciences. 2007;6(5):781787

8. Richards BI, Anaso AB, Bdaliya BS. Effect of seed dressing and cultivar on the incidence and severity of covered and long smut in Nigeria Sudan Savanna. Nigerian Journal of Experimental and Applied Biology. 2008;9(2):65-70.

9. Allard RW, Zhang Q, Maroof MA, et al. Evolution smultiloocus genetic structure in an experimental barley population. Genetics. 1992;131(4):957969.

10. Sinsiri N, Loahasiriwong S, Jogloy S, et al. A varietal screening of cowpea cultivars (Vigna unguiculata) for highest resistance to Pseudocercospora cruenta (Sacc.) Deington in Northern Thailand. Pakistan Journal of Biological Sciences. 2006;9(4):641-648.

11. Plantwise. Leaf spot of cowpea (Mycosphaerella cruenta). USA; 2011. 